\title{
The State of Woody Plants of Natural and Anthropogenic Ecosystems of the European Part of Russia and Their Bioindication Value
}

\author{
Tatiana Gromova \\ Saratov State University \\ Astrakhanskaya Street, 83. \\ Saratov, Russian Federation 410012 \\ Irina Siraeva \\ Saratov State University \\ Astrakhanskaya Street, 83. \\ Saratov, Russian Federation 410012
}

Nikolai Larionov

School No. 2 urban district Kotelniki

Novaya Street, 39.

Kotelniki, Moscow Region, Russian Federation 140054

\author{
Anna Ermolenko \\ Saratov State University \\ Astrakhanskaya Street, 83. \\ Saratov, Russian Federation 410012
}

\author{
Maksim Larionov \\ Balashov Institute of Saratov State University \\ K. Marx Street, 29. \\ Balashov, Saratov Region, Russian Federation 412300 \\ E-mail: m.larionow2014@yandex.ru \\ Tatiana Zavidovskaya \\ Borisoglebsk branch of Voronezh State University \\ Narodnaya Street, 43. \\ Borisoglebsk, Russian Federation 397160
}

\begin{abstract}
Natural and anthropogenic ecosystems of the European part of Russia are quite diverse. Of particular importance for science and practice are environmental studies of urban and suburban natural and anthropogenic ecosystems to establish the state of their functional components - plants that are producents and perform important environmental functions. The complex ecological analysis of parameters of soil and woody plants in different urban functional planning zones and suburban natural and economic objects is carried out. This approach is proposed as an additional universal criterion to the existing system of environmental impact assessment, as it takes into account the multifactorial impact on living organisms and contributes to the objectivity of environmental monitoring.
\end{abstract}

Keywords-natural and anthropogenic ecosystems; soil and ecological indicators; condition of woody plants; biological indication; complex analysis of ecological parameters; the European part of Russia

\section{INTRODUCTION}

Natural and anthropogenic ecosystems are a special kind of ecological systems transformed in the course of various economic activities of people and the entire civilizational development of mankind. Natural and anthropogenic ecosystems can be represented by agrobiocenoses, urban systems, various natural and economic territorial complexes: plant-growing, cattle-breeding, fisheries, forestries, landscape and decorative, hydraulic engineering, transport and economic and others [1] [2].
At large, fully preserved ecosystems, in their reference understanding, have not been practically preserved. Relatively untouched by human activity ecosystems, as close as possible to the original, natural state in their genesis and structural and functional organization, as a rule, are specially protected natural areas. Nevertheless, modern ecological and evolutionary views show that the process of anthropogenesis has affected many ecosystems and even biomes, and already in ancient times, since the early stages of evolution and the gradual resettlement of animal populations of the ancestors of modern man. Taking the new ecological niches has contributed to the improvement of forms of nature management and transformation of new spaces. This has happened in a number of regions of the world, including the European part of Russia.

Acceptable from the environmental point of view, the climate (mainly moderate, moderate continental), the diversity of landscapes, orographic factors, soil and environmental conditions, the diversity of life forms allowed to form different ecosystems in this area.

Urban and suburban landscapes of the European part of Russia currently include a variety of natural and anthropogenic ecosystems that can be differentiated by functional planning zones and features of natural and economic objects and that need to be investigated in detail

The purpose of the work was to analyze the results of long-term (from 2008 to 2018) studies of the ecological state of woody plants depending on the conditions of growth in 
natural and anthropogenic ecosystems of the European part of Russia and to determine the possibility of their use as biological indicators of the environment.

The objects of the research were the soil cover and woody plants in the urban and suburban plantations, as well as woody plants from natural forest communities of suburban areas using the example of the Voronezh, Saratov and Moscow regions, located in Central Russia.

\section{THE MATERIALS AND METHODS OF THE RESEARCH}

The materials of the research were the morphological and ecological indicators and parameters of the sanitary condition of soils indicators of the general sanitary condition of woody plants and anthropogenically caused degradation processes in the process of growth and development in different types of natural and anthropogenic ecosystems of the European part of Russia, where there is higher population density and the highest level of business development and engineering and architectural development of landscapes in comparison with the rest of the state.

In this paper, the results of the following soil-ecological characteristics, including morphological parameters and parameters of the general sanitary state of the soil: structure [3], mechanical composition [4], humidity [5], bulk density, landscaping, sealing, anthropogenic inclusions in the plow word, soil surface debris are analyzed [6] [7] [8] [9].

For each of these soil-ecological parameters a maximum of 5 points was established: from 1 (ecological disaster) to 5 (ecological norm). Therefore, the sum of points for all the established and analyzed in this research criteria was 40 points. As ecological and evaluation criteria, these indicators are used on the basis of scientific and methodological conclusions of M. V. Larionov, who established their importance in the system of ecological diagnostics of transformed landscapes [10] [11] [12].

The ranking of ecological and evaluation points of soil condition was as follows: $36-40$ points - high level of soil stability (ecological norm), 31-35 points - increased level of soil stability, 26-30 points - average stability, 21-25 points low stability, up to $16-20$ points - ecologically unstable soil, less than 15 points - degraded soil (ecological disaster).

The inventory of woody plants and the establishment of sanitary indicators were carried out directly on the ground by visual route method. In urban and suburban areas account routes were represented by the linear stroke length of 800 1000 meters and a width of up to 10 meters (depending on the width of the buffer green zone) full (in urban ecosystems) or partial (in suburban ecosystems) coverage of forest stands in the composition of plantations along the motor roads and around the perimeter of the stationary ecologically significant technospheric objects.

In each urban functional planning zone three accounting routes were investigated. Soil samples were selected to establish their ecological and morphological parameters and bioindicational studies were carried out by the method of test areas. The area method in this case allowed to obtain representative data of environmental monitoring.

In turn, each route has three test areas, provided that they contained 5 model individuals of each species of woody plants used in environmental monitoring as biological indicators. Among the biological indicators, we studied: Betula pendula Roth, Acer platanoides L., Padus avium Mill were studied from among bioindicators., Ulmus laevis Pall., Robinia pseudoacacia L., Picea abies (L.) Karst., Pinus sylvestris L.

For each settlement and the corresponding natural and anthropogenic ecosystems, a control zone was laid in the suburban relatively preserved forests. The control represented a system of three routes in different directions. Their size is similar to that laid in urban conditions. Functional planning zones and control areas were a series of landscapes, where specific natural and anthropogenic ecosystems were formed.

Biological indication included a complex of studied and analyzed features using the following methods of sanitary and environmental assessment of wood plants: determination of the life state by the method of V. T. Yarmishko [13] [14], including the determination of the state of trunks, branches, density (openwork) of the crown, life expectancy of leaves, the presence of signs of chlorosis and necrosis, damage by diseases and pests; the establishment of the levels of biological stability of plants by degree of leafiness, annual growth rate of lateral shoots, winter hardiness, determination of leaf pollution by weight method. These indicators were analyzed in a modified form on a five-point system each. The maximum number of points, taking into account all the estimates are 60 points. The differentiation of the ecological state of woody plants: 51-60 points - the state at the level of ecological norm, 41-50 points - weakly weakened plants (environmentally acceptable state), 31-40 points - strongly weakened plants, up to 30 points - unstable plants (state of degradation).

A complex assessment of the ecological state of woody plants and, accordingly, the conditions of growth was carried out on the basis of summing up the points of the established ecological and morphological and bioindicational parameters in a 100-point system. The distribution of points of integrated environmental assessment: 91-100 points-high environmental sustainability (environmentally friendly state of the environment), 76-90 points - increased sustainability (relatively safe environmental state of the environment), 6175 points - the average degree of environmental sustainability (environmental stress state), 51-60 points - low sustainability (crisis environmental state), up to 50 points unstable plants (environmentally degraded state of the environment). These data were calculated every year, so the estimated tables (1, 2, 3 and 4) indicate the weighted average of points in the form of decimals. Their variants in the cells of columns 2 and 3 are subjected to correlation analysis.

The high objectivity of the final data of the performed monitoring is provided by the representativeness of the samples, a wide territorial coverage, reliability of the results, 
a large number of environmental indicators considered and a complex approach to their assessment.

\section{THE RESULTS OF THE RESEARCH AND THEIR DISCUSSION}

The natural and anthropogenic ecosystems of the European part of Russia are formed within different series of landscapes transformed by economic and construction activities. These ecosystems can be identified by the corresponding functional-planning zones of settlements, specific economic objects and, accordingly, by the types of phytocenoses, including the categories of plantings, which significantly form the appearance and functionality of biocenoses and landscapes.

In fact, the natural and anthropogenic ecosystems in the European part of Russia are confined to specific functional areas of settlements and, in general, to certain natural and economic objects within which they develop.

For plants, the growing conditions are of great importance, since the latter limit their growth processes, development indicators and conditions. In this context, the analysis of soil-ecological conditions is of great importance, since they largely determine the features of the development and the real state of land plants in a particular area.

Among the soil-ecological parameters, morphological features and parameters of the general sanitary condition of the soil cover within the accounting routes and trial areas were established.

The biological indication consisted, firstly, in establishing the sanitary condition and phytopathological status of woody plants in various conditions of urban and suburban natural and anthropogenic systems.

The results for the town of Borisoglebsk (Voronezh region) are processed and presented in the form of evaluation table 1, where the first column contains a series of landscape, the second and third columns - the environmental parameters of soils and plants, the fourth column shows the calculated values of the correlation coefficients, the fifth and sixth columns - the total points and values of the state of woody plants in the relevant territorial complexes.

TABLE I. A COMPLEX ANALYSIS OF THE ECOLOGICAL PARAMETERS OF WOODY PlANTS DEPENDING ON THE PLACE OF GROWTH AND ANTHROPOGENICDEGRADATION FACTORS OF THE TOWN OF BORISOGLEBSK OF VORONEZH REGION AND ITS SUBURBAN AREAS (2008-2018)

\begin{tabular}{|c|c|c|c|c|c|}
\hline \multirow[t]{2}{*}{ Landscape series } & \multirow{2}{*}{$\begin{array}{l}\text { Soil environmental } \\
\text { parameters, points }\end{array}$} & \multirow{2}{*}{$\begin{array}{c}\text { Parameters of } \\
\text { ecological status of } \\
\text { woody plants, points }\end{array}$} & \multirow{2}{*}{$\begin{array}{l}\text { Correlation coefficients } \\
\text { between } 2 \text { and } 3 \text { columns }\end{array}$} & \multicolumn{2}{|c|}{ Ecological state } \\
\hline & & & & Points & Status criteria \\
\hline 1 & 2 & 3 & 4 & 5 & 6 \\
\hline recreational area & $35.1 \pm 1.4$ & $53.2 \pm 1.9$ & 0.78 & 88.3 & increased stability \\
\hline public business areas & $31.9 \pm 1.2$ & $48.5 \pm 1.6$ & 0.73 & 80.4 & increased stability \\
\hline low-rise residential areas & $33.2 \pm 1.3$ & $51.0 \pm 2.1$ & 0.69 & 84.2 & increased stability \\
\hline multi-storeyed residential areas & $30.3 \pm 1.5$ & $49.2 \pm 1.5$ & 0.91 & 79.5 & increased stability \\
\hline industrial zones & $27.4 \pm 1.1$ & $47.4 \pm 1.7$ & 0.97 & 74.8 & $\begin{array}{l}\text { medium degree of } \\
\text { stability }\end{array}$ \\
\hline transport areas & $23.9 \pm 0.7$ & $44.2 \pm 1.6$ & 0.95 & 68.1 & $\begin{array}{l}\text { medium degree of } \\
\text { stability }\end{array}$ \\
\hline communal storage areas & $26.2 \pm 0.9$ & $47.0 \pm 2.0$ & 0.93 & 73.2 & $\begin{array}{l}\text { medium degree of } \\
\text { stability }\end{array}$ \\
\hline $\begin{array}{l}\text { suburban forest belts along } \\
\text { highways }\end{array}$ & $32.5 \pm 1.1$ & $46.1 \pm 1.8$ & 0.88 & 78.6 & increased stability \\
\hline $\begin{array}{l}\text { suburban forest belts along the } \\
\text { perimeter of agrocenoses }\end{array}$ & $33.2 \pm 1.2$ & $50.3 \pm 2.2$ & 0.79 & 83.5 & increased stability \\
\hline suburban forests (control) & $37.2 \pm 1.6$ & $56.9 \pm 2.5$ & 0.84 & 94.1 & high resistance \\
\hline
\end{tabular}

From "Table I" it follows that the best condition of woody plants from an ecological point of view is characteristic of recreational $(88.3$ points, increased sustainable), public and business areas (80.4 points, increased sustainable), areas of residential low-rise development (84.2 points, increased sustainable), as well as suburban forest belts (83.5 points, increased sustainable), located along the perimeter of agricultural communities (grasslands, arable lands, haylands pastures, irrigated and fish ponds), and suburban forest ecosystems (94.1 points). In the latter case (control data) the wood plants are characterized by high ecological stability. Lower values of stability of woody plants, according to the final evaluation points, were found within the production (74.8 points, the average level of environmental sustainability), communal storage areas (73.2 points, similar to the criterion of sustainability) and suburban highway forest belts (78.6 points, the value of increased sustainability). The worst criterion of the condition of woody plants was established for plantation of the traffic zone of the village. Here, the final 68.1 point corresponds to the criterion of average plant resistance.

The obtained differences in the values of environmental parameters with control are statistically significant $(\mathrm{p}<0.05)$.

The revealed indicators of the state of woody plants clearly demonstrate the appropriate levels of transformation and, including the anthropogenic load on the natural and anthropogenic ecosystems of different territories of Borisoglebsk and its suburban areas. In particular, the areas where woody plants are characterized by high resistance correspond to the relative environmental well-being of the environment. The areas where woody plants grow with an average level of environmental sustainability are ecologically tense. Only in the suburban forests the state of stands and, of 
course, the environment is assessed as ecologically safe and ecologically stable.

The calculated values of the correlation coefficient between soil-ecological indicators and ecological parameters showed a positive relationship.

The average score of the complex ecological assessment of the considered group of plants in the city was about 78.4 points, in the suburbs -85.4 points. Therefore, in general, within the city the state of the environment is characterized by environmental well-being. Locally in the town of Borisoglebsk, the danger is posed by the technogenic factors destabilizing the environmental situation in the areas of transport, municipal and industrial functional planning zones.

The obtained results of the complex ecological analysis of woody plants in the town of Balashov, Saratov region are presented in "Table II".

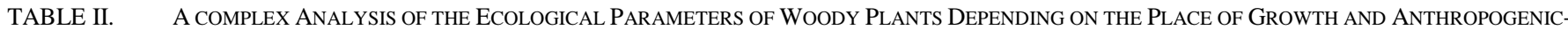
DEGRADATION FACTORS OF THE TOWN OF BALASHOV OF SARATOV REGION AND ITS SUBURBAN AREAS (2008-2018)

\begin{tabular}{|c|c|c|c|c|c|}
\hline \multirow[t]{2}{*}{ Landscape series } & \multirow{2}{*}{$\begin{array}{l}\text { Soil environmental } \\
\text { parameters, points }\end{array}$} & \multirow{2}{*}{$\begin{array}{c}\text { Parameters of } \\
\text { ecological status of } \\
\text { woody plants, points }\end{array}$} & \multirow{2}{*}{$\begin{array}{c}\text { Correlation coefficients } \\
\text { between } 2 \text { and } 3 \\
\text { columns } \\
\end{array}$} & \multicolumn{2}{|c|}{ Ecological state } \\
\hline & & & & Points & Status criteria \\
\hline 1 & 2 & 3 & 4 & 5 & 6 \\
\hline public business areas & $33.2 \pm 1.2$ & $50.3 \pm 2.1$ & 0.93 & 83,5 & increased stability \\
\hline low-rise residential areas & $28.8 \pm 0.9$ & $47.3 \pm 1.9$ & 0.86 & 76,1 & increased stability \\
\hline $\begin{array}{l}\text { multi-storeyed residential } \\
\text { areas }\end{array}$ & $31.3 \pm 1.3$ & $49.1 \pm 1.7$ & 0.89 & 80,4 & increased stability \\
\hline industrial zones & $27.2 \pm 0.8$ & $37.0 \pm 1.5$ & 0.95 & 64,2 & $\begin{array}{l}\text { medium degree of } \\
\text { stability }\end{array}$ \\
\hline transport areas & $23.5 \pm 0.5$ & $48.3 \pm 1.9$ & 0.82 & 71,8 & $\begin{array}{l}\text { medium degree of } \\
\text { stability }\end{array}$ \\
\hline communal storage areas & $18.6 \pm 0.6$ & $44.3 \pm 1.6$ & 0.98 & 62,9 & $\begin{array}{l}\text { medium degree of } \\
\text { stability }\end{array}$ \\
\hline $\begin{array}{l}\text { suburban forest belts } \\
\text { along highways }\end{array}$ & $25.1 \pm 0.7$ & $42.4 \pm 1.7$ & 0.87 & 67,5 & $\begin{array}{l}\text { medium degree of } \\
\text { stability }\end{array}$ \\
\hline $\begin{array}{l}\text { suburban forest belts } \\
\text { along the perimeter of } \\
\text { agrocenoses }\end{array}$ & $28.0 \pm 0.9$ & $44.6 \pm 1.5$ & 0.94 & 72,6 & $\begin{array}{l}\text { medium degree of } \\
\text { stability }\end{array}$ \\
\hline suburban forests (control) & $31.2 \pm 1.3$ & $47.1 \pm 1.8$ & 0.85 & 78,3 & increased stability \\
\hline public business areas & $36.4 \pm 1.7$ & $52.8 \pm 1.9$ & 0.91 & 89,2 & increased stability \\
\hline
\end{tabular}

In comparison with the above-described settlement, in the town of Balashov the final points of the condition of woody plants at the level of high stability are not established, even in the control (89.2 points, the increased level of ecological stability).

The numerical values of the complex environmental analysis of the objects of the research are different from the control indicator. The obtained differences in the analyzed indicators with the control data are in the statistical confidence range $(\mathrm{p}<0.05)$.

The state of woody plants in urban recreational (83.5 points), public and business (76.1 points), low-rise residential areas (80.4 points), as well as in the suburban forest belts around agricultural facilities (78.3 points) is estimated at the level of increased stability. Within these limits, the quality of the environment is characterized by environmental well-being. In the other variants (landscape series) the average degree of stability of wood plants, i.e. the environment has obvious signs of ecological tension. These are the following areas: multi-storeyed residential (64.2 points), industrial (71.8 points), transport (62.9 points), municipal and warehouse (67.5 points), suburban main plantations (72.6 points). The minimal indicators of environmental condition are identified within the urban transport area.
A positive correlation between soil-ecological parameters and the values of the ecological state of the woody plants was obtained.

At the same time, the average score of the complex assessment of the state of woody plants in the city is 72.3 points, in the suburban area -80.0 points. In general, in Balashov there is environmentally tense state of the environment. In the conditions of suburban natural and anthropogenic ecosystems, the state of the environment is objectively better (ecologically safe state of the environment).

"Table III" shows the scores of the complex analysis of the ecological state of the woody plants within the town of Kotelniki, Moscow region and its suburban area. 
TABLE III. A COMPLEX ANAlysis of THE ECOlOGICAl PARAMETERS OF WOOdy Plants DEPENDING ON THE PlaCE OF GROWTH AND ANTHROPOGENICDEGRADATION FACTORS OF THE TOWN OF KOTELNIKI, MOSCOW REGION AND ITS SUBURBS (2017-2018)

\begin{tabular}{|c|c|c|c|c|c|}
\hline \multirow[t]{2}{*}{ Landscape series } & \multirow{2}{*}{$\begin{array}{l}\text { Soil environmental } \\
\text { parameters, points }\end{array}$} & \multirow{2}{*}{$\begin{array}{c}\text { Parameters of } \\
\text { ecological status of } \\
\text { woody plants, points }\end{array}$} & \multirow{2}{*}{$\begin{array}{c}\text { Correlation } \\
\text { coefficients between } 2 \\
\text { and } 3 \text { columns }\end{array}$} & \multicolumn{2}{|c|}{ Ecological state } \\
\hline & & & & Points & Status criteria \\
\hline 1 & 2 & 3 & 4 & 5 & 6 \\
\hline public business areas & $31.9 \pm 1.5$ & $54.3 \pm 2.3$ & 0.87 & 86.2 & increased resistant \\
\hline low-rise residential areas & $31.3 \pm 1.3$ & $52.1 \pm 2.1$ & 0.98 & 83.4 & increased resistant \\
\hline $\begin{array}{l}\text { multi-storeyed residential } \\
\text { areas }\end{array}$ & $30.2 \pm 1.1$ & $46.9 \pm 1.8$ & 0.89 & 77.1 & increased resistant \\
\hline industrial zones & $27.8 \pm 1.2$ & $40.5 \pm 1.6$ & 0.96 & 68.3 & $\begin{array}{l}\text { medium degree of } \\
\text { stability }\end{array}$ \\
\hline transport areas & $21.7 \pm 0.8$ & $37.5 \pm 1.4$ & 0.98 & 59.2 & $\begin{array}{l}\text { low } \\
\text { stability }\end{array}$ \\
\hline communal storage areas & $17.4 \pm 0.5$ & $39.2 \pm 1.5$ & 0.99 & 56.6 & $\begin{array}{l}\text { low } \\
\text { stability }\end{array}$ \\
\hline $\begin{array}{l}\text { suburban forest belts along } \\
\text { highways }\end{array}$ & $22.3 \pm 0.9$ & $37.8 \pm 1.4$ & 0.96 & 60.1 & $\begin{array}{l}\text { low } \\
\text { stability }\end{array}$ \\
\hline $\begin{array}{l}\text { suburban forest belts along } \\
\text { the perimeter of agrocenoses }\end{array}$ & $25.1 \pm 1.1$ & $40.3 \pm 1.8$ & 0.97 & 65.4 & $\begin{array}{l}\text { medium degree of } \\
\text { stability }\end{array}$ \\
\hline suburban forests (control) & $28.2 \pm 1.0$ & $44.7 \pm 1.9$ & 0.88 & 71.9 & $\begin{array}{l}\text { medium degree of } \\
\text { stability }\end{array}$ \\
\hline public business areas & $33.2 \pm 1.5$ & $48.1 \pm 1.6$ & 0.95 & 81.3 & increased resistant \\
\hline
\end{tabular}

This table shows that in the conditions of suburban forests the condition of woody plants is estimated at 81.3 points, which means their increased environmental sustainability. However, in comparison with the other two settlements, the minimum scores have been established in this case. In general, this is due to the increasing processes of urbanization and the development of diverse economic complex, which is expressed in increased pressure on the surrounding ecosystems, including the forest. This tendency is typical for the majority of urban settlements in close proximity to Moscow.

The maximum score (demonstrating increased stability) corresponds to the recreational ( 86.2 points), social and business (83.4 points) and low-rise residential functional and planning zones (77.1 points). Here, the quality of the environment is assessed at the level of environmentally friendly. The minimum scores of the complex ecological analysis of woody plants were revealed for industrial (59.2 points), transport (56.6 points) and municipal storage areas (60.1 points). In them, woody plants are characterized by low resistance. Accordingly, in these areas the crisis ecological state of the environment is established. The average degree of ecological stability of woody plants was revealed in multistoreyed residential areas (68.3 points), suburban forest belts along highways (65.4 points), suburban forest belts of agricultural facilities (71.9 points). Within these areas, the ecologically tense state of the environment is noted.

The differences in the ecological parameters of plants with the control are valid $(\mathrm{p}<0.05)$.

A positive correlation between the soil-ecological parameters and the parameters of the state of woody plants was established.

About the town of Kotelniki the average score of the integrated ecological assessment of woody plants corresponds to 70.1 points (ecological stress state of the environment), in the suburban area -72.7 points (similar value of the state of the environment).

It should be noted that now in many cities of the European part of Russia much attention is paid to the improvement of recreational and social and business areas, their landscaping, the creation of presentable landscape compositions of various lawns with decorative plantations and original architectural solutions. To a greater extent that is expressed in Moscow region, in the less - in Saratov and Voronezh regions.

In the settlements of the European part of Russia, recreational facilities are being intensively created and reconstructed. Landscaping of the surrounding areas to residential, public-business and industrial areas is carried out. Therefore, the environmental situation with the state of recreational and public-business areas can be improved, as in Moscow region that is given increased attention.

At the same time, the studies have shown that in towns of the European part of Russia transport zones are the leading aggregate source of environmental pollution, degradation of structural and functional state of soils and sanitary and ecological quality of tree plantations.

In cities, including in regional centers, taking into account the more developed transport and economic infrastructure and higher intensity of traffic flows, the environmental situation in the area of transport and spatial contact with its neighboring functional areas is tense and even crisis.

A great contribution to the degradation of tree plantations and the environment is made by mobile and stationary technogenic objects: motor road, railway and aviation (in Moscow region) transport, large and small industrial complexes, repair and service stations, fuel distribution and fuel stations, shopping and business centers, street trade and services, communal services. 
Taking into account the growth of the total number of different types of transport, the anthropogenic load on fragile natural and anthropogenic ecosystems is constantly growing. It is possible to predict with a high degree of confidence that the environmental situation will have a trend to deterioration.

\section{CONCLUSION}

Among the studied towns the maximum technogenic press has the natural and anthropogenic ecosystems in Kotelniki, the minimum - in Borisoglebsk. The general high pressure of anthropogenic factors on the environment, including the tree plantations of the town of Kotelniki is due to its proximity to Moscow, which is the largest industrial, transport, logistic and economic center in the Russian Federation. The major role here is also played by the development and complexity of the transport system, its high load compared to the towns of Voronezh, Saratov regions and other regions.

These are production, transport and communal storage areas. The latter are also becoming more important.

For all the studied towns local ecological phenomena presenting degradation processes due to the activities of technosphere is characterized. Those are industrial, transport and communal storehouse zones. The latter acquire a greater importance.

The revealed positive correlation between the ecological indicators of soil and woody plants indicates the need to study soil and environmental conditions and a complex analysis of their impact on plant organisms in different areas.

The presented environmental indicators and the corresponding methods used are the means of group biological indication, that is, when environmental diagnostics of environmental objects use not individual organisms, but their totality, which increases the representativeness and accuracy of the assessment.

The approach used for integrated ecological assessment of the state of woody plants in various categories of plantings and natural forest ecosystems is a reliable and objective method of landscape biological indication.

The determination of the quality of the environmental situation within specific natural and anthropogenic systems and landscapes, as a whole, is a new approach in the system of environmental assessment of the environment and in the analysis of the main functional components of the environmental frameworks of certain territorial complexes. The fact is that in the landscape, as is known, organisms are affected by a complex of factors, including the anthropogenic plan. In connection with modern trends of the development of the national economy and transformation of natural components in environmental diagnosis of the environment it is advisable to use an integrated approach of the analysis of environmental and evaluation criteria of the soil cover and plants as the most important environments in its composition, depositing various anthropogenic agents and by this being the factors of stabilization between the natural and anthropogenic components of the environment.
Plants, primarily woody, used in landscaping of cities, towns, villages and other anthropogenically transformed systems, integrated or discrete (primarily in spatial and object context) environmental engineering, reforestation activities, land reclamation and recultivation of urban landscape and agricultural land, transport and various natural-economic areas perform important functions: environmental-forming and environmental-regulating, aesthetic, therapeutic (improves health and other psychophysiological parameters of health, reduce fatigue, various painful conditions) and other ecological and hygienic roles in the environment.

In total, tree plantations play an environmentally limiting role in relation to the results of technogenic loads on the environment, significantly contributing to the ecological balance between natural and man-made components of landscapes. In view of its main ecological role - the creation of primary products in ecosystems, as well as environmentalforming and environmental-regulating functions, they provide environmental comfort for the life and work of people, as they form the basis of the supporting ecological frameworks of various natural and anthropogenic systems, including those considered in this paper.

Therefore, as part of the environmental assessment system, in addition to the methods of physical and chemical analysis of soil and atmosphere, some of which are mandatory in stationary environmental monitoring, in the conditions of urban and rural settlements, transport and economic, agricultural, forestry facilities and other natural and anthropogenic ecosystems, it is necessary to use the proposed methodological approach of an integrated landscape and bioindication analysis of various territories. It deserves a lot of attention from researchers and environmental specialists due to the impressive researchanalytical and methodological potential in terms of the development of knowledge, theory and practice in the field of environmental assessment and, in particular, in the field of the development of state environmental monitoring. That is especially true for the natural and anthropogenic systems of the European part of Russia.

\section{REFERENCES}

[1] N. Yu. Vinogradova "Global ecology", Moscow: Education, 2001, $310 \mathrm{p}$.

[2] V. A. Vronsky "Applied ecology", Rostov-on-Don: Phoenix, 1996, $512 \mathrm{p}$.

[3] S. A. Zakharov "A course of soil science", Moscow: Gosizdat, 1927, $455 \mathrm{p}$.

[4] N. A. Kachinsky "Mechanical and microaggregate soil composition, methods of its study", Moscow: Publishing house of the USSR Academy of Sciences, 1958, $191 \mathrm{p}$.

[5] N. A. Kachinsky "The Physics of soil", part 1, Moscow: Higher school, 1965, $324 \mathrm{p}$.

[6] M. V. Larionov "Complex assessment of technogenic pollution of urban areas of the Middle and Lower Volga region and progressive technologies aimed at its reduction": doctoral dissertation on biological sciences, Bryansk, 2013, 512 p.

[7] M. V. Larionov "Some morphological and physical parameters of soils as ecological and diagnostic categories of transformed 
landscapes": collection of articles of the II International scientific and practical conference (Penza, October 22-23, 2015), Penza: PSAU publishing house, 2015, pp. 101-105.

[8] M. V. Larionov "Ecological monitoring of urban environment: monograph", Saratov: Saratov source, 2015, 104 p.

[9] Guidelines for the assessment of urban soils in the development of urban planning and architectural and construction documentation, Moscow: JSC Mosproekt, 2003, 24 p.

[10] M. V. Larionov "Complex assessment of technogenic pollution of urban areas of the Middle and Lower Volga region and progressive technologies aimed at its reduction": doctoral dissertation on biological sciences, Bryansk, 2013, pp. 138-139.

[11] M. V. Larionov "Some morphological and physical parameters of soils as ecological and diagnostic categories of transformed landscapes": collection of articles of the II International scientific and practical conference (Penza, October 22-23, 2015), Penza: PSAU publishing house, 2015, pp. 102-103.

[12] M. V. Larionov "Ecological monitoring of urban environment: monograph", Saratov: Saratov source, 2015, pp. 53-55.

[13] V. T. Yarmishko "Methods of studying forest communities in conditions of disturbed habitats", Methods of studying forest communities, Saint-Petersburg: SRI of Chemistry SPbSU publishing house, 2002, pp. 51-52.

[14] V. T. Yarmishko "Common pine and atmospheric pollution in the European North", Saint-Petersburg: SRI of Chemistry SPbSU publishing house, 1997, pp. 91-95. 